\title{
Respiration in the scyphozoan jellyfish Aurelia aurita and two hydromedusae (Sarsia tubulosa and Aequorea vitrina): effect of size, temperature and growth
}

\author{
Lene Friis Møller*, Hans Ulrik Riisgård
}

Marine Biological Research Centre, University of Southern Denmark, Hindsholmvej 11, 5300 Kerteminde, Denmark

\begin{abstract}
The effect of body size on respiration was examined in the common scyphozoan jellyfish Aurelia aurita (ephyrae and medusae) and in 2 hydromedusae, Sarsia tubulosa and Aequorea vitrina. The starvation respiration rate $\left(R_{\mathrm{M}}, \mu l \mathrm{O}_{2} \mathrm{~d}^{-1}\right)$ as a function of dry body weight $(W, \mathrm{mg})$ could be expressed by means of the equation $R_{\mathrm{M}}=a W^{b}$, and was determined to be $18.9 W^{0.76}$ for $A$. aurita (ephyrae and medusae), $19.4 W^{0.91}$ for $S$. tubulosa, and $2.39 W^{1.02}$ for $A$. vitrina. Further, the effect of temperature, feeding and growth on respiration was studied in $A$. aurita. The weight-specific respiration rate $\left(R_{\mathrm{W}}, \mu \mathrm{O} \mathrm{O} \mathrm{O}_{2}[\mathrm{mg} d r y \mathrm{wt}]^{-1} \mathrm{~d}^{-1}\right)$ increased exponentially with temperature $\left(T,{ }^{\circ} \mathrm{C}\right)$ within the 7 to $22^{\circ} \mathrm{C}$ interval at $R_{\mathrm{W}}=0.93 \mathrm{e}^{0.11 T}\left(Q_{10}=3.1\right)$. A. aurita ephyrae responded rapidly to the presence of food, and maximum respiration rate was attained after $4 \mathrm{~h}$; after the supply of food was stopped, the respiration rate decreased to the starvation level within $2.5 \mathrm{~h}$. Respiration was measured in A. aurita that were fed different concentrations of an assortment of prey organisms (copepods, rotifers, cirriped larvae, Artemia sp.) to obtain a spectrum of specific growth rates. The weightspecific respiration rate as a function of the weight-specific growth rate was linear, and from the slopes of the regression lines the energetic cost of growth was found to be equivalent to $209 \%$ of the growth of A. aurita ephyrae feeding on a variety of prey organisms, and 69 and $42 \%$ of the growth of A. aurita medusae preying on Artemia sp. and Acartia tonsa respectively.
\end{abstract}

KEY WORDS: Respiration · Temperature effect · Size effect · Cost of growth · Specific dynamic action · $\mathrm{SDA} \cdot$ Aurelia aurita $\cdot$ Sarsia tubulosa $\cdot$ Aequorea vitrina

Resale or republication not permitted without written consent of the publisher

\section{INTRODUCTION}

The ecological significance of jellyfish is of great interest because they often occur in high densities and biomasses in costal waters and estuaries and, due to the fact that both hydrozoans and scyphozoans prey on zooplankton and fish larvae, they may have a large impact on the pelagic food web (Möller 1978, Purcell 1997, Mills 2001). During the boreal summer, the common jellyfish Aurelia aurita has the potential to control zooplankton in Limfjorden (Denmark) (Hansson et al. 2005), Kertinge Nor (Denmark) (Olesen 1995) and Kiel Bight (Germany) (Behrends \& Schneider 1995). Jellyfish often have high growth rates and during summer they frequently account for the greatest proportion of plankton biomass (Möller 1978). Therefore, when evaluating the carbon cycle in marine environments, it is important to include the predation impact, growth and respiration of jellyfish.

Several studies have examined oxygen consumption in different gelatinous zooplankton species, but most of these have concentrated on effect of size (e.g. Biggs 1977, Larson 1987). However, when applying laboratory respiration measurements to field data, temperature may also be an important factor to consider. To date, no thorough studies on respiration rate as a function of temperature in hydrozoans or scyphozoans have been conducted. 
Besides size and temperature, the respiration rate of jellyfish may also be influenced by food uptake and subsequent growth. Rate of respiration increases when an animal is feeding and growing: a phenomenon often designated as specific dynamic action (SDA) (Grisolia \& Kennedy 1966, Kiørboe et al. 1985). In addition to the energy actually deposited as new tissue, growth processes require energy to fuel the biochemical reactions of biosynthesis. The extra energy used to fuel growth is reflected by an increase in the oxygen consumption of a growing animal, also described as the respiratory cost of growth (Kiørboe et al. 1985, Conceicão et al. 1997, Peterson et al. 1999, Thor 2000, 2002).

The aim of the present study was to examine the effect of size, temperature and growth on respiration in the Aurelia aurita. The effect of growth on respiration rate was measured in jellyfish fed different concentrations of an assortment of prey organisms, in order to obtain a spectrum of specific growth rates as a tool to determine the cost of growth. In addition, the effect of size was studied in the hydromedusae Sarsia tubulosa and Aequorea vitrina.

\section{MATERIALS AND METHODS}

Medusae were collected from Kertinge Nor (salinity 14 to $22 \mathrm{psu}$ ), a shallow cove in the northern part of Fyn, Denmark, from Skive Fjord (salinity 25 psu), a shallow inner branch of Limfjorden in the northern part of Jutland, Denmark, and from the outer part of the Gullmar Fjord on the west coast of Sweden. Gullmar Fjord has a maximum depth of $120 \mathrm{~m}$ and is always stratified. Salinity is always 34 to $35 \mathrm{psu}$ in the bottom water and below 30 psu in the surface water. Adult Aurelia aurita were collected from Kertinge Nor during the summer of 2004 and 2005, whereas Aequorea vitrina were collected from Skive Fjord in August 2004. A. aurita ephyrae were collected at both sites during the spring of 2004 and 2005. Sarsia tubulosa were collected during spring 2006 from Gullmar Fjord. The medusae were brought to the laboratory and kept in storage aquaria $\left(15^{\circ} \mathrm{C}, 20\right.$ psu for $A$. aurita, A. aequorea, and $17^{\circ} \mathrm{C}, 34 \mathrm{psu}$ for $S$. tubulosa) until experiments could be performed. If kept for longer than a few days, the jellyfish were fed Artemia sp. nauplii.

Respiration, measured as oxygen consumption, was recorded in 2 types of set-ups using 2 different types of electrodes

(1) Respiration in Aurelia aurita and Aequorea vitrina was measured by means of an oxygen electrode (CellOx 325) connected to an oxygen-measuring instrument (Oxi 197i). The electrode was placed in a flowthrough chamber connected by tubes to a respiration chamber holding the animals. Air bubbled filtered sea water was pumped through the chambers by means of a peristaltic pump. Measurements were initiated by closing the system so that the water was re-circulated through the respiration chamber past the electrode and back again. Each measurement was followed by a control measurement without jellyfish. The volumes of respiration chambers used varied from $25 \mathrm{ml}$ to 100 l, and the no. of individuals varied from 5 to 15 . The flow rate in the system was $5 \mathrm{ml} \mathrm{min}^{-1}$. The electrode was calibrated in an OxiCal-SL air calibration vessel

(2) Respiration in Sarsia tubulosa was measured by polygraphic oxygen electrodes connected through an amplifier to a computer mounted with data acquisition hardware (Computer Boards CIO-DAS 802), again using the re-circulation technique described above. Four experimental chambers (with jellyfish) and 2 control chambers (without jellyfish) were monitored simultaneously. Oxygen concentration was measured every $10 \mathrm{~s}$, and averages of 6 consecutive measurements were stored every minute. The respiration chambers had a volume of $4 \mathrm{ml}$ and the flow rate was $0.15 \mathrm{ml}$ $\mathrm{min}^{-1}$. One medusa was placed in each experimental chamber. Electrodes were calibrated using oxygen saturated water $\left(100 \% \mathrm{O}_{2}\right.$ saturation) and a sodium sulfite solution $(0 \%)$

Oxygen concentration was plotted as a function of time and expressed by a linear regression line. The respiration rate was calculated as: $R\left(\mathrm{mg} \mathrm{O}_{2} \mathrm{~min}^{-1}\right)=$ $b \times\left(V \times \mathrm{n}^{-1}\right)$, where $b$ is the slope of the regression $\left(\mathrm{mg} \mathrm{l}^{-1} \mathrm{~min}^{-1}\right), V$ is the volume of water in the respiration vessel and tubes (l), and $\mathrm{n}$ is the no. of individuals. Oxygen consumption in the control was subtracted from $R$ to obtain the respiration rate of the jellyfish. The total respiration rate $\left(R_{\mathrm{T}}\right)$ was defined as: $R_{\mathrm{T}}=$ $R_{\mathrm{M}}+R_{\mathrm{G}}$, where $R_{\mathrm{M}}$ is the starvation respiration, and $R_{\mathrm{G}}$ is the respiration due to growth. The weight-specific respiration $\left(R_{\mathrm{W}}\right)$ was defined as: $R_{\mathrm{W}}=R_{\mathrm{T}} \times W^{-1}$, where $W$ is the dry body weight.

The behaviour of medusae in the respiration chamber was observed during the experiment to ensure natural behaviour. Experiments were run for no longer than $45 \mathrm{~min}$ and the oxygen saturation of the water never fell below $80 \%$. Unless stated otherwise, all measurements were made at $15^{\circ} \mathrm{C}$.

The size-dependent maintenance respiration rate was calculated as the starvation ( 2 d) respiration of medusae (Aurelia aurita, Sarsia tubulosa, Aequorea vitrina) of different sizes. Measurements of $S$. tubulosa were made at $17^{\circ} \mathrm{C}$.

Effect of temperature change on respiration rate was measured in Aurelia aurita $(\varnothing \pm \mathrm{SD}=39.9 \pm 0.9 \mathrm{~mm})$ within the interval 7 to $22^{\circ} \mathrm{C}$. The temperature was controlled by means of a thermostatted water bath. The medusae were acclimatized for $1 \mathrm{wk}$ to $15^{\circ} \mathrm{C}$ and maintained at the new temperature for about $1 \mathrm{~h}$ be- 
fore starting a new measurement. Effect of feeding on respiration rate was measured in initially starved A. aurita ephyrae $(\varnothing \pm \mathrm{SD}=4.7 \pm 1.2 \mathrm{~mm})$. These were subsequently fed rotifers ( 800 ind. $\mathrm{l}^{-1}$ ) both during and between repeated measurements, and total respiration rate was measured at certain time intervals after the onset of feeding. To correct for respiration of the rotifers, control experiments were made with rotifers in the respiration chamber. Effect of starvation on respiration rate was measured in $A$. aurita ephyrae $(\varnothing \pm \mathrm{SD}$ $=5.1 \pm 1.3 \mathrm{~mm}$ ) at certain time intervals after termination of the growth experiments.

Growth experiments were conducted with Aurelia aurita (ephyrae and medusae) at $15^{\circ} \mathrm{C}$. The jellyfish were
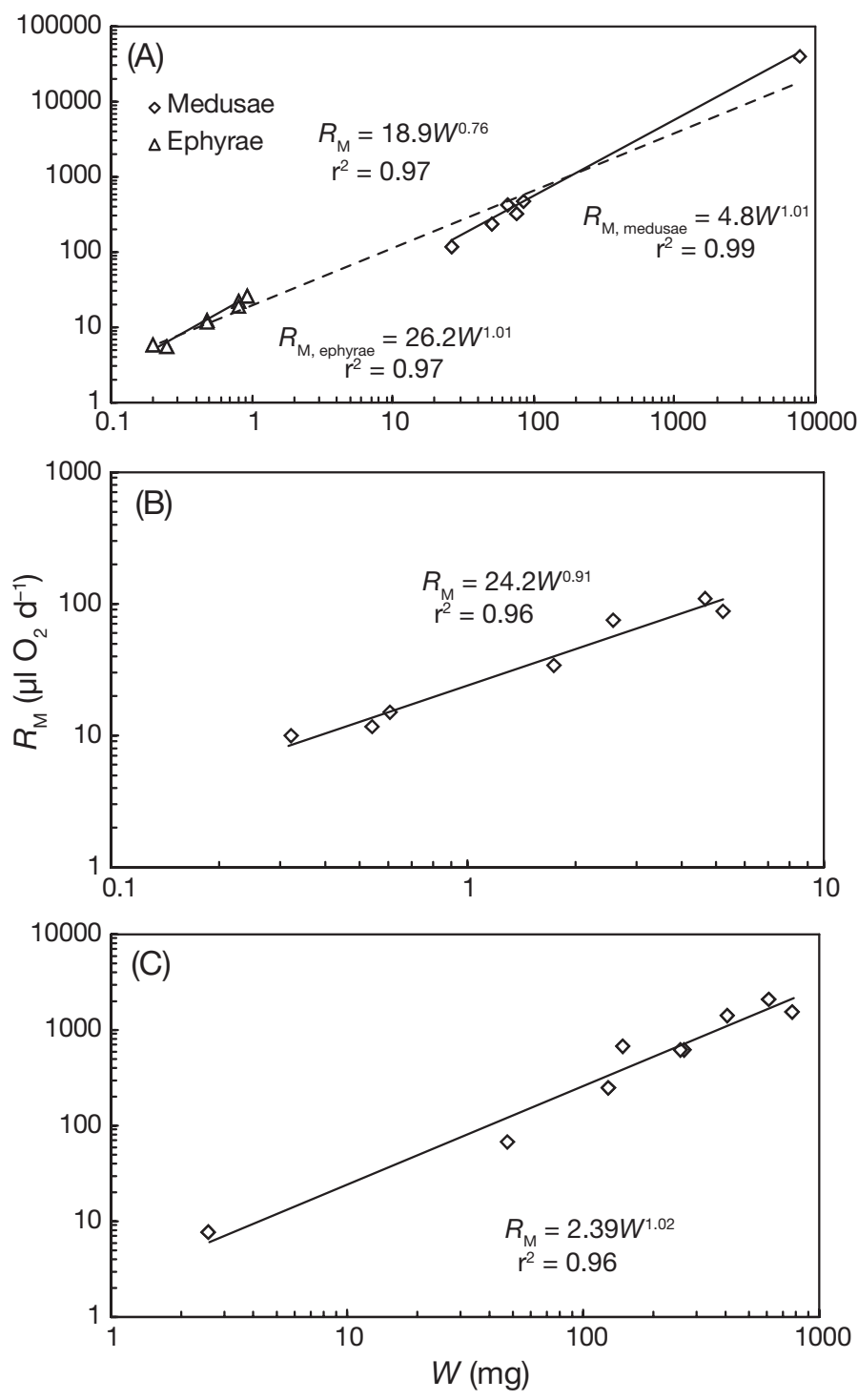

Fig. 1. (A) Aurelia aurita. (B) Sarsia tubulosa. (C) Aequorea vitrina. Log maintenance (starvation) respiration rate $\left(R_{\mathrm{M}}\right)$ as a function of log dry body wt $W$ offered different assortments of prey at different concentrations to obtain a spectrum of specific growth rates. Aurelia aurita ephyrae and medusae were offered Artemia salina and adult Acartia tonsa as prey, and ephyrae were additionally fed Brachionus sp. and Balanus sp. nauplii/cypris. The diameter of medusae was measured at the beginning and end of the experimental period (4 d). Every day, medusae were transferred to an aquarium with new seawater containing the same initial prey concentration as used the previous day, and the remaining prey organisms in the old water were collected on a $80 \mu \mathrm{m}$ filter and counted. The specific growth rate $\left(\mu, \mathrm{d}^{-1}\right)$ was determined as: $\mu=\ln \left(W_{t} \times W_{0}^{-1}\right) \times t^{-1}$, where $W_{t}$ and $W_{0}$ is dry body wt at time 0 and $t$ respectively. The respiration rate was measured immediately after termination of the growth experiments.

Conversion factors. The following equations were used to estimate dry wt ( $W, \mathrm{mg}$ ) from umbrella diameter $(D, \mathrm{~mm})$. Aurelia aurita ephyrae: $W=1.913 \times 10^{-3} D^{2.998}$ (Båmstedt et al. 1999); A. aurita medusae ( $\geq 20 \mathrm{~mm}): W=$ $0.004 D^{2.7}$ (L. Møller \& H. Riisgård unpubl. data); and Aequorea vitrina: $W=0.03 D^{2.3}$ (L. Møller \& H. Riisgård unpubl. data). For Sarsia tubulosa, bell height $(H, \mathrm{~mm})$ was converted to carbon content $\left(W_{\mathrm{C}}, \mu \mathrm{g} C\right)$ using the equation $W_{\mathrm{C}}=0.443 H^{3.10}$ (Daan 1986), and $W$ was determined as follows. Sarsia sp.: $1 \mathrm{mg}$ dry wt $=3.5 \mathrm{~J}=67 \mu \mathrm{g} \mathrm{C}$ (Schneider 1988, Matsakis \& Conover 1991); ephyra: $1 \mathrm{mg}$ dry wt $=3.66 \mathrm{~J}=70 \mu \mathrm{g} \mathrm{C}$; and medusae: $1 \mathrm{mg}$ dry $\mathrm{wt}=2.24 \mathrm{~J}=50 \mu \mathrm{g} \mathrm{C}$ (Schneider 1988). $1 \mathrm{~J}$ corresponds to $50 \mu \mathrm{O}_{2}$.

\section{RESULTS}

Fig. 1 shows the maintenance respiration rate as a function of dry body wt in starved individuals of Aurelia aurita (ephyrae and adult medusae), Sarsia tubulosa and Aequorea vitrina. Linear relationships are observed in log-log plots, and for all regression equations the $b$ exponent is close to 1 .

The acute effect of temperature on the maintenance respiration rate of Aurelia aurita acclimatized to $15^{\circ} \mathrm{C}$ is shown in Fig. 2. The respiration rate increased exponentially with temperature within the interval 7 to $22^{\circ} \mathrm{C}$.

The weight-specific respiration rate as a function of specific growth rate in Aurelia aurita ephyrae and medusae is shown in Fig. 3. The highest specific growth rate obtained in any given experiment was the maximum specific growth rate observed for the respective medusa species and size. In all cases, a linear correlation was found. Further, for ephyrae of A. aurita, variable rates were obtained when different prey were supplied. In Fig. 3A, a regression line was fitted to rates obtained when rotifers were supplied as prey, in addition to a regression line fitted to the entire 


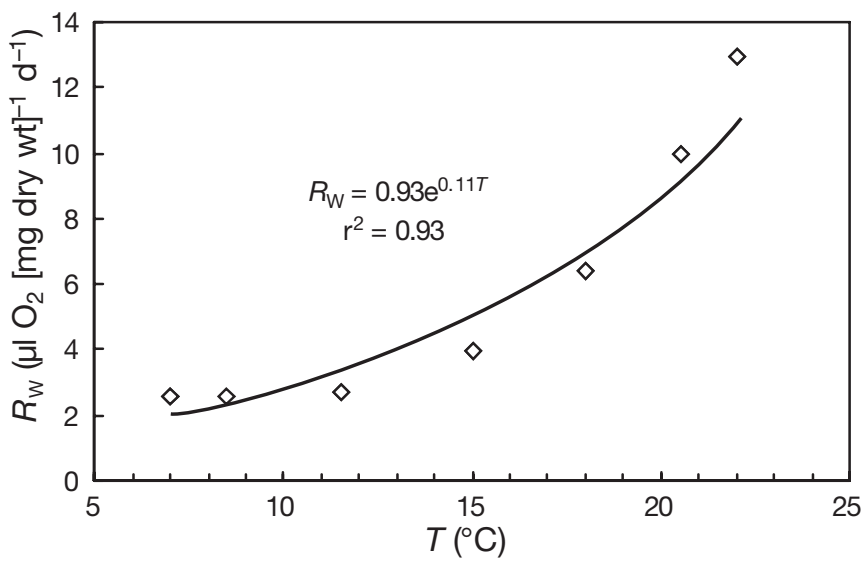

Fig. 2. Aurelia aurita. Weight-specific respiration rate $\left(R_{\mathrm{W}}\right)$ as a function of temperature

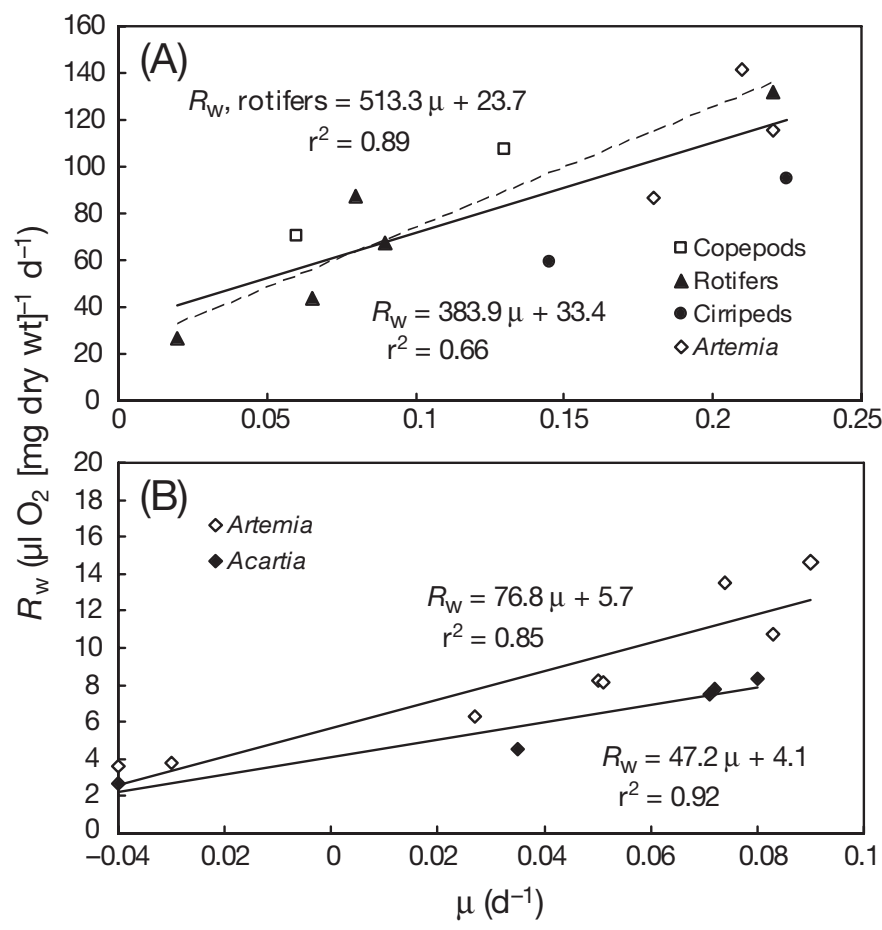

Fig. 3. Aurelia aurita. Weight-specific respiration rate $\left(R_{\mathrm{W}}\right)$ as a function of specific growth rate, $\mu$. (A) Ephyrae. Dashed line: regression when rotifers were used as prey; solid line: regression fitted to all prey. (B) Medusae

data set. The respiration rate of $A$. aurita medusae also varied according to whether Artemia sp. or Acartia tonsa were used as prey; thus, a regression line was fitted separately to each of the two prey types (Fig. 3B). The slopes of these regression lines were significantly different (Student's $t$-test: $\mathrm{p}<0.001$ ).

The effect of feeding on the respiration of Aurelia aurita ephyrae is shown in Fig. 4. After measuring the respiration in starved individuals, where the weight-

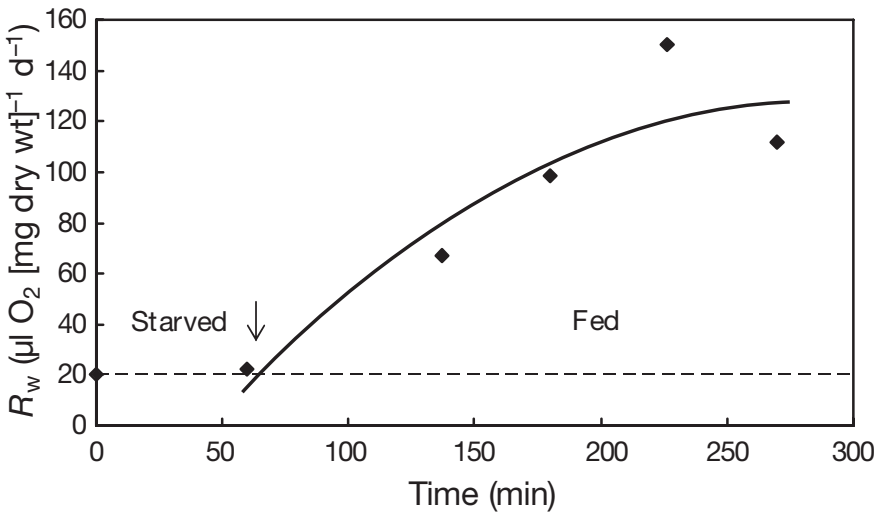

Fig. 4. Aurelia aurita (ephyrae). Weight-specific respiration rate $\left(R_{\mathrm{W}}\right)$ in starved and fed individuals as a function of time (arrow indicates beginning of food addition). Dashed line: starvation weight-specific respiration rate

specific respiration was constant $\left(\sim 20 \mu \mathrm{l} \mathrm{O}_{2}\right.$ [mg dry $\left.\mathrm{wt}]^{-1} \mathrm{~d}^{-1}\right)$, ephyrae were fed rotifers $\left(\sim 800\right.$ ind. $\left.\mathrm{l}^{-1}\right)$ both during and between the 4 subsequent respiration measurements. The weight-specific respiration rate subsequently increased up to $120 \mu \mathrm{O}_{2}$ (mg dry wt) ${ }^{-1} \mathrm{~d}^{-1}$ within about $3 \mathrm{~h}$.

The effect of starvation on the weight-specific respiration rate of Aurelia aurita ephyrae, which had an initial specific growth rate of $0.20 \mathrm{~d}^{-1}$, was demonstrated by a decrease in $R_{\mathrm{W}}$ from $87 \mu \mathrm{O}_{2}$ (mg dry wt) ${ }^{-1} \mathrm{~d}^{-1}$ at the beginning of the starvation period to $30 \mu l \mathrm{O}_{2}(\mathrm{mg}$ dry $w t)^{-1} \mathrm{~d}^{-1}$ after $2.5 \mathrm{~h}$.

\section{DISCUSSION}

It is well-known that the respiration rate $(R)$ of an animal as a function of body weight $(W$ ) can usually be expressed by means of a power function $R=a W^{b}$, where the scaling exponent $b$ is typically 0.75 ; however, this function is not universal (Riisgård 1998). Larson (1987) studied respiration in 12 different species of hydrozoans and scyphozoans and found that $b$ exponents did not differ significantly from 1 .

In the present study, the relationship between starvation respiration rate and body dry wt was determined for Aurelia aurita (ephyrae and medusae), Aequorea vitrina and Sarsia tubulosa, and all $b$ exponents were close to 1 (Fig. 1). Further, the weight-specific respiration rates obtained in the present study seemed to be in fairly good agreement with most literature values (Table 1).

The weight-specific starvation respiration rate was found to increase exponentially with temperature in Aurelia aurita (Fig. 2); $Q_{10}$ was calculated to be 3.1 from the relationship $Q_{10}=\mathrm{e}^{(10 \times \text { slope })}$, where the slope is the exponent obtained from regression analysis of respiration 
Table 1. Weight-specific respiration rate $\left(R_{\mathrm{W}}\right)$ in various scyphozoans and hydrozoans

\begin{tabular}{|c|c|c|c|c|}
\hline $\begin{array}{l}\text { Taxonomic group } \\
\text { and species }\end{array}$ & $R_{\mathrm{W}} R_{\mu \mathrm{O} \mathrm{O}_{2} \mathrm{~d}^{-1}(\mathrm{mg} \text { dry wt })^{-1}}$ & $\mu \mathrm{l} \mathrm{O} \mathrm{O}^{-1}(\mu \mathrm{g} C)^{-1}$ & $T\left({ }^{\circ} \mathrm{C}\right)$ & Source \\
\hline \multicolumn{5}{|l|}{ Scyphozoa } \\
\hline Aurelia aurita (ephyra) & $\begin{array}{l}22.1-27.6 \\
26.4\end{array}$ & $0.3-0.4$ & $\begin{array}{c}15 \\
10-15\end{array}$ & $\begin{array}{l}\text { Present study } \\
\text { Kinoshita et al. (1997) }\end{array}$ \\
\hline Aurelia aurita (medusae) & $\begin{array}{c}4.3-6.7 \\
2.4-4.8 \\
\quad 4.8\end{array}$ & $0.08-0.13$ & $\begin{array}{c}15 \\
10-15\end{array}$ & $\begin{array}{l}\text { Present study } \\
\text { Kinoshita et al. (1997) } \\
\text { Larson (1987) }\end{array}$ \\
\hline Cyanea capillata & 16.7 & & 15 & Larson (1987) \\
\hline \multicolumn{5}{|l|}{ Hydrozoa } \\
\hline Sarsia tubulosa & $17-31$ & $0.3-0.5$ & 17 & Present study \\
\hline Sarsia princeps & 4.8 & & 10 & Larson (1987) \\
\hline Aequorea vitrina & 2.4 & & 15 & Present study \\
\hline Aequorea victoria & 2.4 & & 10 & Larson (1987) \\
\hline
\end{tabular}

as a function of temperature. Larson (1987) listed $Q_{10}$ values for several species of hydrozoans and scyphozoans that were in the range of 1.4 to 5.3 , with a mean of 3 .

In the present study, Aurelia aurita ephyrae responded rapidly to the presence of food and the maximum respiration rate was reached after $\sim 4 \mathrm{~h}$ (Fig. 4). After maximum weight-specific respiration rates had been obtained and the food supply was withdrawn, the respiration rate decreased to starvation levels within $\sim 2.5 \mathrm{~h}$. The fast response of respiration to changes in food availability indicates that $A$. aurita is well adapted to utilizing patches of food.

An increase in respiration as a response to feeding and growth has not previously been measured in hydrozoans or scyphozoans, even though a few attempts have been made to measure the effects of feeding and growth. Arai (1986) studied respiration in fed Aequorea victoria but did not observe higher respiration rates in fed compared with starved individuals. Olesen et al. (1994) measured total respiration in Aurelia aurita with different specific growth rates, but did not find respiration to be higher in growing individuals. Similar results were obtained by Frandsen \& Riisgård (1997), who argued that this might be due to a rapid decline in SDA within their measurement time (6 h). Our study supports this arguement.

In the present study, weight-specific respiration $R_{\mathrm{W}}$ was also measured in individuals with different specific growth rates (Fig. 3). The $R_{\mathrm{W}}$ of Aurelia aurita ephyrae and medusae increased $\sim 6$ - and 3.5-fold, respectively, from starved individuals to individuals with maximum specific growth rates. Similar results have been obtained in other species. In e.g. Acartia tonsa, the respiration of individuals that were fed at saturating food concentrations increased 4 -fold when compared with that of starved individuals (Kiørboe et al. 1985).
According to Kiørboe et al. (1987), total respiration (defined in the present study as $R_{\mathrm{T}}=R_{\mathrm{M}}+R_{\mathrm{G}}$ ) may also be written as $R_{\mathrm{T}}=a W^{b}+n \mu W$ or $R_{\mathrm{T}} \times \mathrm{W}^{-b}=a+n \mu \mathrm{W}^{1-b}$, where $W$ is body dry wt, $a$ and $b$ are constants, $n$ is the energy cost per unit of growth (production) and $\mu$ is specific growth rate. Since the exponent $b \cong 1$ (Fig. 1), the equation reduces to $R_{\mathrm{W}}=a+n \mu$. If the specific respiration rate and specific growth rate are expressed with same unit $\left(\mathrm{d}^{-1}\right), n$ becomes a constant and expresses the energy cost per unit of growth (see also Riisgård 1998). For example, $n$ is expressed by the slopes of the regression lines in Fig. 3. For ephyrae (all data points), $n=383.9 \mu \mathrm{O} \mathrm{O}_{2}$ (mg dry wt) ${ }^{-1}$, and the energetic cost of growth was calculated to be equivalent to $209 \%$ (i.e. $383.9 \div 183$ ) of growth, since $1 \mathrm{mg}$ dry wt $=2.24 \mathrm{~J}=$ $3.66 \mathrm{~J}=183 \mu \mathrm{l} \mathrm{O}$. Likewise, the energetic cost of growth was found to be equivalent to 69 and $42 \%$ of the growth in Aurelia medusae (1 $\mathrm{mg}$ dry wt $=2.24 \mathrm{~J}=$ $112 \mu \mathrm{O}_{2}$ ) when preying on Artemia sp.and Acartia tonsa respectively. The cost of growth found for jellyfish in the present study is quite high compared to values for most other marine invertebrates (see review by Riisgård 1998).

The cost of biomass formation depends on which macromolecules are primarily being synthesized (proteins, lipids, carbohydrates) (Thor 2000, Thor et al. 2002). There is growing evidence that protein synthesis accounts for most of the SDA in marine invertebrates (Carefoot 1990, Houlihan et al. 1995, Thor 2002). If the monomers required for biosynthesis are not available in the diet in sufficient amounts, the energetic cost of growth becomes higher (Kiørboe et al. 1985). This may account for the fact that, in the present study, cost of growth varied depending on the type of prey. Results obtained from adult Aurelia aurita medusae feeding on Acartia tonsa or Artemia sp. re- 
vealed a significant difference in cost of growth depending on prey type (Fig. 3B). A similar dependence on food quality was found for e.g. Acartia tonsa (Thor et al. 2002). The observed difference in cost of growth for $A$. aurita ephyrae and medusae may be related to their different biochemical composition: ephyrae have a higher protein content ( $30 \%$ of total dry wt) than medusae (10\% of total dry wt) (Lucas 1994).

In the future, when estimating food requirements in the field from laboratory energy budgets, it is important that the cost of growth for jellyfish is incorporated. The present study indicates that, to date, the food requirements of growing jellyfish have been underestimated, and that these organisms may have a greater predation effect on mesozooplankton than previously assumed.

Acknowledgements. This study formed part of the EUROGEL project (EVK3-CT-2002-00074). Thanks are due to Dr. Peter Thor for constructive comments on the manuscript and for lending us the respiration set-up used for Sarsia tubulosa.

\section{LITERATURE CITED}

Arai MN (1986) Oxygen consumption of fed and starved Aeqourea victoria (Murbach and Shearer, 1902)(Hydromedusae). Physiol Zool 59:188-193

Båmstedt U, Lane J, Martinussen MB (1999) Bioenergetics of ephyrae larvae of the scyphozoan jellyfish Aurelia aurita in relation to temperature and salinity. Mar Biol 135:89-98

Behrends G, Schneider G (1995) Impact of Aurelia aurita medusae (Cnidaria, Scyphozoa) on the standing stock and community composition of mezozooplankton in the Kiel Bight (western Baltic Sea). Mar Ecol Prog Ser 127:39-45

Biggs DC (1977) Respiration and ammonium excretion by open ocean gelatinous zooplankton. Limnol Oceanogr 22: 108-117

Carefoot TH (1990) Specific dynamic action (SDA) in the supralittoral isopod, Liga pallasii: identification of components of apparent SDA and effects of dietary amino acid quality and content on SDA. Comp Biochem Physiol 95A: 309-316

Conceicão LEC, Houlihan DF, Verreth JAJ (1997) Fast growth, protein turnover and costs of protein metabolism in yolk-sac larvae of the African catfish (Clarias gariepinus). Fish Physiol Biochem 16:291-302

Daan R (1986) Food intake and growth of Sarsia tubulosa (Sars, 1835) with quantitative estimates of predation on copepod populations. Neth J Sea Res 20:67-74

Frandsen KT, Riisgård HU (1997) Size dependent respiration and growth in jellyfish Aurelia aurita. Sarsia 82:307-312

Grisolia S, Kennedy J (1966) On specific dynamic action, turnover, and protein synthesis. Perspect Biol Med 9: $578-583$

Hansson LJ, Moeslund O, Kiørboe T, Riisgård HU (2005) Clearance rates of jellyfish and their potential predation

Editorial responsibility: Howard Browman (Associate Editorin-Chief), Storebø, Norway impact on zooplankton and fish larvae in a neritic ecosystem (Limfjorden, Denmark). Mar Ecol Prog Ser 304: $117-131$

Houlihan DF, Pedersen BH, Steffensen JF, Brechin J (1995) Protein synthesis, growth and energetics in larval herring (Clupea harengus) at different feeding regimes. Fish Phys Biochem 14:195-208

Kinoshita J, Hiromi J, Kadota S (1997) Do respiratory metabolic rates of the scyphomedusa Aurelia aurita scale isometrically throughout ontogeny in a sexual generation. Hydrobiologia 347:51-55

Kiørboe T, Møhlenberg F, Hamburger K (1985) Bioenergetics of the planktonic copepod Acartia tonsa: relation between feeding, egg production and respiration, and composition of specific dynamic action. Mar Ecol Prog Ser 26:85-97

Kiørboe T, Munk P, Richardson K (1987) Respiration and growth of larval herring Clupea harengus: relation between specific dynamic action and growth efficiency. Mar Ecol Prog Ser 40:1-10

Larson RJ (1987) Respiration and carbon turnover rates of medusae from the NE Pacific. Comp Biochem Physiol 87A: 93-100

Lucas CH (1994) Biochemical composition of Aurelia aurita in relation to age and sexual maturity. J Exp Mar Biol Ecol 183: 179-192

Matsakis S, Conover RJ (1991) Abundance and feeding of medusae and their potential impact as predators on other zooplankton in Bedford Basin (Nova Scotia, Canada) during spring. Can J Fish Aquat Sci 48:1419-1430

Mills CE (2001) Jellyfish blooms: Are populations increasing globally in response to changng ocean conditions? Hydrobiologia 451:55-68

Möller H (1978) Significance of coelenterates in relation to other plankton organisms. Meeresforschung 27:1-18

Olesen NJ (1995) Clearance potential of jellyfish Aurelia aurita, and predation impact on zooplankton in a shallow cove. Mar Ecol Prog Ser 124:63-72

Olesen NJ, Frandsen K, Riisgård HU (1994) Population dynamics, growth and energetics of jellyfish Aurelia aurita in a shallow fjord. Mar Ecol Prog Ser 105:9-18

Peterson CC, Walton BM, Bennett AF (1999) Metabolic costs of growth in free-living garter snakes and the energy budgets of ectotherm. Funct Ecol 13:500-507

Purcell JE (1997) Pelagic cnidarians and ctenophores as predatores: selective predation, feeding rates and effects on prey populations. Ann Inst Océanogr 73:125-137

Riisgård HU (1998) No foundation of a '3/4 power scaling law' for respiration in biology. Ecol Lett 1:71-73

Schneider G (1988) Chemische Zusammensetzung und Biomasseparameter der Ohrenqualle Aurelia aurita. Helgol Meeresunters 42:319-327

Thor P (2000) Relationship between specific dynamic action and protein deposition in calanoid copepods. J Exp Mar Biol Ecol 245:171-182

Thor P (2002) Specific dynamic action and carbon incorporation in Calanus finmarchicus copepodites and females. J Exp Mar Biol Ecol 272:159-169

Thor P, Cervetto G, Besiktepe S, Ribera-Maycas E, Tang KW, Dam HG (2002) Influence of two different green algal diets on specific dynamic action and incorporation of carbon into biochemical fractions in the copepod Acartia tonsa. J Plankton Res 24:292-300

Submitted: April 7, 2006; Accepted: June 19, 2006

Proofs received from author(s) January 15, 2007 